\title{
Racial Sympathy and Support for Capital Punishment: A Case Study in Concept Transfer
}

Kellie R. Hannan ${ }^{1}$, Francis T. Cullen ${ }^{2}$, Leah C. Butler ${ }^{3}$, Amanda Graham ${ }^{4}$, Alexander L. Burton ${ }^{2}$, and Velmer S. Burton, $\mathrm{Jr}^{5}$

${ }^{1}$ College of Business Administration, University of Cincinnati

${ }^{2}$ School of Criminal Justice, University of Cincinnati

${ }^{3}$ School of Criminal Justice and Criminology, University of Nebraska at Omaha

${ }^{4}$ Department of Criminal Justice and Criminology, Georgia Southern University

${ }^{5}$ Department of Criminal Justice, University of Arkansas at Little Rock

\section{Recommended Citation:}

Hannan, K. R., Cullen, F. T., Butler, L. C., Graham, A., Burton, A. L., \& Burton, Jr., V. S. (2020). Racial sympathy and support for capital punishment: A case study in concept transfer. Working paper, University of Cincinnati 


\title{
Racial Sympathy and Support for Capital Punishment: A Case Study in Concept Transfer
}

\begin{abstract}
Beliefs about race, especially racial resentment, are key predictors of public support for capital punishment and punitiveness generally. Drawing on a conceptual innovation by political scientist Jennifer Chudy, we explore the utility of transferring into criminology her construct of racial sympathy_or Whites' concern about Blacks' suffering. First, across three data sets, we replicate Chudy's finding that racial sympathy and resentment are empirically distinct constructs. Second, based on a national-level 2019 YouGov survey $(n=760$ White respondents $)$ and consistent with Chudy's thesis, racial sympathy is then shown to be significantly related to the race-specific view that capital punishment is discriminatory but not support for the death penalty or harsher courts. Racial sympathy also is positively associated with advocacy of rehabilitation as the main goal of prison. Notably, in all models, racial resentment has robust effects, increasing punitive sentiments. Taken together, the results suggest that racial sympathy is a concept that can enrich criminologists' study of how race shapes crime policy preferences in the United States and beyond.
\end{abstract}

Keywords Racial sympathy; racial resentment; capital punishment; public policy 
Virtually no inquiry focusing on race and criminal justice can ignore the momentous events unfolding on the nation's streets in the aftermath of the police killing of George Floyd and the lengthy list of the unarmed Black victims before him. Sustained insurgency by African Americans has shown the Black community's frustration with the social and justice-system inequities that are reproduced in police use of force, especially against people of color. Research reveals that, compared to Whites, African Americans are 2.3 times more likely to be killed by law enforcement officers (Zimring, 2017) and over 5 times more likely than Whites to worry about police brutality — what Graham and colleagues (2020, p. 1) refer to as a "hidden injury of minority status."

The protest movement, however, has been remarkable in another way: the large number of Whites whose concern for George Floyd and other victims has moved them, in the midst of a pandemic, to don masks and march in communities from coast to coast. These sentiments are widely shared, with $49 \%$ of White adults supporting versus $26 \%$ opposing the protests ( $25 \%$ did not express a view) (Easley, 2020). Heartfelt concern and calls for action have come from all sectors, including professional athletes and prominent coaches, entertainers, corporations, and the American Society of Criminology itself. ${ }^{1}$ At the presidential level, a stark choice has been offered. Donald Trump has portrayed demonstrators as "thugs," threatened to call out the U.S. military to quash insurgency, labeled governors "weak" for not "dominating" protesters, and held up a Bible in a photo-op in front of St. John's Episcopal Church after Attorney General Bill Barr instructed police and National Guard troops to forcibly clear out media personnel and peaceful protesters (Chappell, 2020; Miller, Lemire, \& Balsamo, 2020; Wise, 2020). "He did not pray," observed Bishop Mariann Edgar Buddle. "He did not offer a word of balm or condolence to those who are grieving" (Miller et al., 2020). By contrast, Joe Biden conducted a listening 
session at Bethel African Methodist Episcopal Church in Wilmington, Delaware, to hear the "black community express their collective anguish" (Astor, 2020). In Philadelphia, the former Vice President announced it was time "for the nation to deal with systemic racism" and promised "to heal the racial wounds that have long plagued our country" (Glueck, 2020).

These events demonstrate the importance of "racial sympathy" — a concept recently introduced by political scientist Jennifer Chudy (in press, p. 5; see also Chudy, 2017, 2018) and defined as "white distress over black suffering." This racial belief will likely prove critical in how White Americans interpret the George Floyd incident captured on videotape, their openness to criminal justice reform, and who they will seek to elect in upcoming elections. In a criminological coincidence, as the tragedy at Minneapolis occurred, we were completing final revisions on a manuscript calling for the transfer of Chudy's concept of racial sympathy from political science into our discipline. Our concern was mainly methodological — to present a case study in how an important new concept might be imported into criminology systematically. We called this a case study both because the specific transfer of racial sympathy was important in and of itself and to make the broader point that criminology should use the approach reported here as an example to guide disciplinary concept transfers in the future. But beyond this goal, the substantive salience of racial sympathy in the current context is palpable. How Whites think and feel about African Americans might well matter in any policy efforts to address the challenge of police violence and, more broadly, systemic racism in the justice system and beyond.

To explore the potential relevance of racial sympathy to policy preferences, we chose to focus on public support for capital punishment and related punitive attitudes. We did so because race is inextricably entwined with these public opinions and because Chudy argued that racial 
sympathy's effects should occur precisely when a social policy is race-related. Thus, research shows that there has been a long-standing racial divide in support for state executions, with the split between Blacks and Whites typically hovering around 25 percentage points (Butler, Unnever, Cullen, \& Thielo, 2018; Johnson, 2008; Unnever \& Cullen, 2007a; Unnever, Cullen, \& Jonson, 2008). Even though death penalty support has declined in the past quarter-century from $80 \%$ to 54\%, this racial divide persists ("Death Penalty," 2019). Thus, a 2018 poll by the Pew Research Center revealed a gap of 23 percentage points, with $59 \%$ of Whites compared with $36 \%$ of Blacks favoring the death penalty for those convicted of murder (Oliphant, 2018).

Importantly, this racial divide has raised the question of why Whites are more supportive of capital punishment. Scholars have documented that racial beliefs are linked to such punitiveness (see Butler et al., 2018). In particular, research has consistently shown that racial animus or resentment toward African Americans is a key source of Whites' embrace of capital punishment (see, e.g., Bobo \& Jonson, 2004; Unnever \& Cullen, 2007b, 2010b; Unnever et al., 2008). In fact, negative racial and ethnic sentiments are related more generally to punitive attitudes, including cross-culturally (Unnever \& Cullen, 2010a, 2010b; Unnever et al., 2008).

As will be noted, Donald Kinder, a political scientist at the University of Michigan, has been prominent in measuring and studying the effects on policy opinions of racial resentment. More recently, his doctoral students have undertaken research extending the study of racial beliefs and their consequences (see, e.g., Chudy, 2017; Jardina, 2019). Most relevant here is Chudy's (in press, 20187, 2018) analyses showing that public policy opinions among Whites are shaped not only by racial resentment but also by racial sympathy. Those with racial sympathy are more likely to support policies beneficial to African Americans, such as government aid to Blacks and affirmative action. She demonstrates as well that such sympathy diminishes 
punitiveness toward Black offenders. Although limited, research in criminology shows that orientations such as compassion, empathy, and religious forgiveness are related to less support for capital punishment and to lower levels of punitiveness (see, e.g., Applegate, Cullen, Fisher, \& Vander Ven, 2000; Godcharles, Rad, Heide, Cochran, \& Solomon, 2019; Metcalfe, Pickett, \& Mancini, 2015; Unnever \& Cullen, 2007a; Unnever, Cullen, \& Applegate, 2005, Unnever, Cullen, \& Bartkowski, 2006; Unnever, Cullen, \& Fisher, 2005). More generally in the social sciences, a call exists to explore a range of racial views, including Whites' racial apathy (Brown, Bento, Gorman, Koku, \& Culber, 2019; Forman \& Lewis, 2006) and racial emotions (BonillaSilva, 2019).

In this context, the current project seeks to build on Chudy's contribution within political science by assessing the merits of transferring or importing this concept of racial sympathy into criminology. To do so, three issues are addressed. First, methodologically, we examine whether racial sympathy and racial resentment are distinct constructs. Do the items measuring these two racial beliefs load on different factors in factor analyses or, alternatively, on the same factor, indicating that they are two ends of the same attitudinal spectrum? Second, as noted, racial resentment is a robust predictor of punitiveness, including the death penalty. We explore whether this effect remains when racial sympathy is included in the same analysis. Is support for capital punishment tied more closely to animus or to sympathy toward Blacks? Do both racial beliefs have effects, or does one belief render the other spurious? Third, beyond capital punishment, how are racial sympathy and resentment related to a progressive policy opinionspecifically, support for rehabilitation as a goal of imprisonment?

As noted, this investigation is best seen as a case study in "concept transfer." Criminology focuses on a distinct subject matter — crime-related phenomena—but as a social 
science, it draws on and is enriched by knowledge from other disciplines. The use of racial resentment as a standard measure in studies of racial beliefs and public policy opinion is a clear example of concept transfer from political science to criminology. Forthcoming in the prestigious The Journal of Politics, Chudy's (in press) work falls within this same scholarly tradition (again, influenced heavily by Donald Kinder of the University of Michigan) and promises to be a major contribution in political science. Its relevance to criminology thus seems important to explore. As a prelude to doing so, Chudy's contributions are considered, with a focus on the concept, measurement, and empirical consequences of racial sympathy.

\section{Racial Sympathy}

\section{Concept}

With the emergence of the civil rights movement and public rejection of outward expressions of racism, scholars observed the decline — though not the disappearance — of more traditional forms of racism (known as "Jim Crow racism" or "blatant racism") carrying the view of "African Americans as genetically and socially inferior" (Kawakami, Dion, \& Dovidio, 1998; Unnever et al. 2008, p. 64). Instead, they documented a related form of racial animus embedded in "a combination of race hostility and traditional American values" (Kinder \& Sanders, 1996, p. 293) that views minorities' disadvantaged state as being due to their own individual failings and as exacting undeserved governmental "handouts." Early terms for this concept included “modern racism" (McConahay 1982), "laissez-faire racism" (Bobo, Kluegel, \& Smith, 1997), or "symbolic racism" (Henry \& Sears, 2002). Kinder and Sanders (1996) were the first to define this concept as "racial resentment," or, the idea that "discrimination was illegal, opportunities were plentiful. Blacks should work their way up without handouts or special favors in a society that was now color-blind" (Kinder \& Sanders, 1996, p. 105). Their scale is now the standard 
measure of this concept - and the one used in the current study. Importantly, racial resentment has proven to be a consistently strong predictor not only of punitive crime-control policies but also of a range of other outcomes, such as opposition to gun control policies (Filindra \& Kaplan, 2016; O'Brien, Forrest, Lynott, \& Daly, 2013). More broadly, research shows that racial resentment is a predictor of a range of social policy attitudes, again fostering views that oppose a social welfare approach to addressing disadvantage in American society (Feldman \& Huddy, 2005; Kinder \& Sanders, 1996; Henderson \& Hillygus, 2011; Hutchings \& Valentino, 2004; Tuch \& Hughes, 2011; Unnever et al., 2008).

Recently, Jennifer Chudy (2017, 2018, in press) has sought to expand inquiry into the impact of racial attitudes on public policy preferences. Although recognizing the salience of racial resentment, she argues that White views on race are marked not only by animus but also by more positive sentiments, including sympathy for minorities. Her project was thus to invent a new construct — racial sympathy — and to show its influence on public policy opinions.

For Chudy (in press), such "sympathy is foremost a racial attitude" (p. 3, emphasis in original). She defines this new construct as follows: "In the United States, racial sympathy refers to white distress over black suffering" (in press, p. 5). Racial sympathy is not a dichotomous sentiment but rather exists on a continuum. As Chudy (in press) notes: "It is best conceptualized on a spectrum: those high in racial sympathy experience severe distress over black suffering, which they perceive to be prevalent, while those low in racial sympathy are indifferent to black suffering, which they perceive to be negligible" (p. 5).

Chudy (in press) is careful to distinguish racial sympathy from racial prejudice, noting that sympathy "is not the mere opposite of racial prejudice" (p. 3). This observation leads to her key insight that racial sympathy "is not merely the absence of prejudice, it is the presence of 
distress" (p. 7, emphasis in original). In fact, she argues that a "lack of prejudice does not create sympathy for African American suffering" (p. 8). Further, although it is likely that racial sympathy and prejudice would be negatively correlated, they are not mutually exclusive views. "Since racial sympathy is independent from racial prejudice," notes Chudy (in press), "it is possible that a white individual could possess both attitudes simultaneously" (p. 8).

\section{Measurement}

Beyond the conceptual innovation of advancing the idea of racial sympathy, the value of Chudy's enterprise hinges on measurement- that is, on whether it can be shown that racial prejudice and sympathy are in fact separate constructs. One possibility is that prejudice and sympathy are two ends of the same attitudinal spectrum. In this scenario, items in a scale that measure prejudice and sympathy would be highly inter-correlated and, in a factor analysis, load onto a single factor. They would thus be tapping the same underlying latent construct. Items assessing racial sympathy would merely be asking about racial prejudice in the opposite direction, perhaps to avoid acquiescence bias (Pickett \& Baker, 2014). They would be reverse coded in the subsequent multivariate analysis.

In her dissertation at the University of Michigan co-chaired by Donald Kinder, Chudy (2017) addressed this methodological issue, seeking to demonstrate that racial sympathy was not only conceptually but also empirically distinct from racial prejudice. Her approach involved three steps. First, consistent with the evolution of the study of racism, her research design included a measure of racial resentment drawn from Kinder and Sanders (1996) — “a four-item scale, which researchers have found to be a strong predictor of race-relevant policy predictors" (2017, p. 61). This scale "focuses on levels of support for statements featuring negative traits 
and stereotypes about African Americans, such as the view that blacks do not try hard enough to get ahead" (2017, p. 61).

Although they initially used a six-item racial resentment scale ${ }^{2}$, in order to replicate their analyses, Kinder and Sander's (1996) measure was reduced to the four items that had been used consistently across the 1986, 1988, and 1992 National Election Studies surveys. They explain that the four-item scale - the same used in the current study and in Chudy's research — excludes the two questions from the six-item scale that are the "least justifiable as measures of prejudice (on the interpretation that prejudicial beliefs are erroneous)" and that may be confounded with their dependent variable (public policy on race) because they "explicitly invoke government" (Kinder \& Sanders, 1996, p. 120). Thus, the number of items used in subsequent scholarship varies, but the four items used in the current study and in Chudy's research are standard (see, e.g., Bobo \& Johnson, 2004; Feldman \& Huddy, 2005; Henderson \& Hillygus, 2011; Johnson, 2008; Segura \& Valenzuela, 2010; Unnever \& Cullen, 2007b).

Second, in a key innovation, Chudy (2017, see also 2018, in press) developed a measure of racial sympathy. Chudy (2018) recognized that, although evident, racial sympathy can be documented throughout history (e.g., Whites' advocacy for the emancipation of slaves, participation in the civil rights movement, and support of affirmative action). Attempts to measure racial sympathy prior to Chudy have either (1) measured racial sympathy as the inverse of racial prejudice, or (2) conflated attitudes of sympathy, empathy, and compassion into a single measure (see, e.g., Dovidio \& Gartner, 2004; Iyer, Leach, \& Crosby, 2003). Thus, she sought to develop a measure of racial sympathy as its own independent construct.

Chudy conducted preliminary qualitative work, interviewing participants of a broader series of programming hosted by the College of Literature, Science and the Arts at the University 
of Michigan. Her qualitative methods "ranged from semi-structured discussions following a museum exhibit to a casual dialogue after a play with racial themes" (Chudy, 2018, pp. 10-11; see also Chudy, 2017). The results showed that Whites' responses to Blacks' suffering were more often sympathetic rather than empathetic. In other words, their responses primarily tended toward distress over Blacks' suffering as opposed to the participants expressing their ability "to relate to the experiences of blacks" (2018, p. 10, emphasis in original). Chudy's preliminary work also suggested that Whites' sympathetic feelings were in "reaction to tangible, personal misfortune experienced by blacks," and therefore "were not abstract and principled notions of equality" (2018, pp. 11-12).

Based on her findings that Whites primarily responded to the misfortunes experienced by Blacks with feelings of sympathy, and that these responses were evoked when given concrete examples of such misfortune, Chudy (2017) developed a series of four vignettes that described instances of Blacks experiencing racial discrimination. After reading each vignette, the respondents were asked the level of sympathy they felt toward the person or people described in the vignette and were given answer choices from "I do not feel any sympathy" to "A great deal of sympathy" (Chudy 2017, p. 57). Chudy's (2017) vignette measure differs from prior measures of concepts similar to racial sympathy because it "enabled subjects to react directly to specific stimuli rather than abstract notions of discrimination and inequality" while only asking about feelings of sympathy (not empathy and compassion) (pp. 39-40). These vignettes are listed in Appendix A.

To test the reliability, validity, and predictive power of this new measure, Chudy (2017, 2018) undertook a national-level study that included her vignette measure of racial sympathy and the standard measure of racial resentment. The index was administered on a module of the 2013 
Cooperative Congressional Election Study (CCES) fielded in November 2013 by

YouGov/Polimetrix. The 2013 CCES sample is a national web-based sample and the developed vignettes were distributed to 1,000 respondents with 751 identifying as White. She assessed the Cronbach's alpha of each scale, with the racial sympathy alpha being .74 and the racial resentment alpha being .87. The scales are also shown to be negatively related $(r=-.45)$. Furthermore, in earlier studies using Amazon's Mechanical Turk (MTurk), Chudy found lower correlations between racial sympathy and racial resentment $(r=-.19$, and $r=-.40)$. This conveys the concepts are "related, but not interchangeable" (Chudy, 2018, p. 15). Then, most importantly, using her CCES sample, a factor analysis revealed that racial sympathy and racial resentment load on separate factors, indicating that they are indeed independent constructs.

After having established her concepts as being distinct, Chudy then examined their effects on public policy preferences. She finds that racial sympathy has a significant effect on Whites' support for government aid to blacks, increased federal spending on welfare programs, government "subsidies for black businesses," "funding for schools in black neighborhoods", and "scholarships for qualified black students," though racial sympathy does not have a significant effect on Whites' support for affirmative action (Chudy, 2018, p. 18).

The association between racial sympathy and policy opinion, even when controlling for racial resentment, "suggests that the racial sympathy index is capturing unique dimensions of racial attitudes that low animus cannot" (Chudy, 2018, p. 17). Her results show that although racial resentment, party identification, and support for limited government have a significant effect on certain policy attitudes, they do not, however, explain away the effect of racial sympathy. Chudy's key idea is that racial sympathy only has effects on policies that have a racial component. She finds that racial sympathy is not a significant predictor of support for 
women's affirmative action, opposition to abortion rights, or support for a government requirement for women's unpaid parental leave.

Of particular interest for the current study is Chudy's use of an experimental vignette factorial design in which respondents were randomly assigned one of two versions of a "crime blotter" that "depicted a fictitious black neighborhood which had recently been the target of graffiti" (Chudy, 2018, p. 23). In the first version, the photograph of the culprit was White, and in the second version, the photograph of the culprit was Black. Respondents were then asked to indicate the number of community service hours to which they believe the culprit should be sentenced.

Her results show that White respondents who scored high on the racial sympathy scale assigned "roughly half the amount of community service to a black culprit than they [did] a white culprit for the same offense" (Chudy, 2018, p. 23). This finding suggests that although racially sympathetic Whites "are not generally anti-punitive...they are significantly less likely to inflict a harsh punishment on a black person who commits an identical offense" (p. 24). The current study builds upon Chudy's concept of racial sympathy and further probes its relationship to punitive crime attitudes.

\section{Research Strategy}

The current project seeks to explore the potential impact of racial sympathy on support for capital punishment and, secondarily, on punitiveness. The approach proceeds in three stages. First, using data from a 2019 national-level YouGov survey, supplemented with two MTurk surveys also conducted in 2019, we replicate Chudy's (2017, in press) analysis demonstrating that racial sympathy is a unique construct empirically distinct from racial resentment. The goal is to establish racial sympathy as a construct and measure that can be applied in the examination 
of racial attitudes within criminology and social science more generally. As shown, this appears to be the case. Notably, these findings are important not just for criminology but also for political science because they provide independent confirmation of Chudy's work outside her home discipline.

Second, we then assess whether racial sympathy reduces support for capital punishment. This analysis has two important features. The first is that consistent with Chudy's (2018) hypothesis that racial sympathy has race-specific effects, measures are included not only for global support for the death penalty but also for whether capital punishment in the United States is applied in a racially discriminatory way. Because research has shown that similar constructs such as empathy decrease support for the death penalty (see, e.g., Unnever, Cullen, \& Fisher, 2005), it is possible that racial sympathy might have a comparable effect. Regardless, Chudy (2017, in press) would hypothesize that racial sympathy would heighten the likelihood that Americans would see capital punishment as discriminatory. The second feature concerns the effects of racial resentment versus racial sympathy. As noted, racial resentment is a robust predictor of death penalty attitudes (Bobo \& Jonson, 2004; Unnever \& Cullen, 2007b, 2010b; Unnever et al., 2008). At issue is whether racial sympathy will exert effects with racial resentment in the same model, and other control variables. If racial animus is the driving force connecting race to the embrace of the death penalty, then it is possible that it will render spurious any association between racial sympathy and this policy preference.

Third, moving beyond capital punishment, we explore whether racial sympathy has general effects on policy opinions, asking respondents about their support for two policies long measured in polls (Cullen, Fisher, \& Applegate, 2000; Enns, 2016). The first is support for "harsher courts," which captures a more global punitiveness. The second is support for 
rehabilitation as the main goal or "emphasis" of imprisonment. The inclusion of rehabilitation is important because it is a progressive policy preference. Although inversely related, punishment and treatment attitudes are distinct and can be held simultaneously (Cullen et al., 2000; Mears, Pickett, \& Mancini, 2015; Sloas \& Atkin-Plunk, 2019; see also Unnever, Cochran, Cullen, \& Applegate, 2010). It is possible that racial sympathy might not only diminish death penalty support and punitiveness but also heighten advocacy for offender treatment.

Finally, an obvious concern is that any effects attributed to racial sympathy might be due to respondents holding a global orientation for caring for others. As noted, prior studies have, in fact, reported that constructs such as compassion, empathy, and religious forgiveness decrease punitiveness, including support for the death penalty (Applegate et al., 2000; Godcharles et al., 2019; Metcalfe et al., 2015; Unnever \& Cullen, 2007a; Unnever, Cullen, \& Applegate, 2005; Unnever et al., 2006; Unnever, Cullen, \& Fisher, 2005). To address this issue, the analysis includes a measure of "care/harm," one of the five foundations of morality identified by Haidt (2012). According to Haidt (2012), those high on this foundation are concerned "about harm and suffering” (p. xxi) and manifest "compassion," "caring," and "kindness" (p. 146). Research shows that, with some nuances (e.g., focus of the sanction, combined with justice/fairness foundation), caring/harm is negatively related to punitiveness (see, e.g., Silver \& Silver, 2017; Silver, 2017; Vaughan, Holleran, \& Silver, 2019). We also include a measure for “egalitarianism," which assesses support for equality in society and for making efforts to facilitate everyone's success. As such, this variable could be considered another "control" for a caring orientation toward others (see also Chudy, 2017).

\section{Methods}

\section{Sample}


To assess the effects of racial attitudes on the outcome variables, we commissioned YouGov to conduct the survey, which we developed and supplied, between June 7-10, 2019. The sample included 1,200 U.S. adult (18 and over) respondents.

What distinguishes YouGov's methods from other opt-in internet surveys is their twostage sample matching design (Mercer, Kreuter, Keeter, \& Stuart, 2017). YouGov first selects a matched sample of respondents from its volunteer online panel of 2 million U.S. adults. The selected respondents are matched on a joint distribution of a large number of covariates (e.g., race, education, political party affiliation) to a synthetic sampling frame, using distance matching. The synthetic sampling frame is constructed from probability samples (e.g., Current Population Survey, American Community Survey) and propensity scores are created to weight the YouGov sample in accordance to the probability samples (Ansolabehere \& Rivers, 2013; Vavreck \& Rivers, 2008). Because of the matching and weighting procedures YouGov uses, sample selection biases are minimized.

Evidence exists showing that findings from YouGov surveys generalize to the U.S. population (Ansolabehere \& Schaffner 2014; Kennedy et al. 2016; Sanders, Clarke, Stewart, \& Whiteley, 2007; Simmons and Bobo 2015). Further, several studies have even found that YouGov's sampling design rivals, if not outperforms, probability sampling methods (Kennedy et al., 2016; Vavreck \& Rivers, 2008). These findings, combined with the widespread publication of YouGov data in the leading social science journals and on a range of public policy issues, lend credence to the conclusion that YouGov data are now a standard source of public opinion data (Thielo, Graham, \& Cullen, in press).

Given the study's focus on racial resentment and sympathy toward Blacks, the sample was limited to White respondents $(n=770)$ - as was the case in Chudy's research. Due to 
missing data, the weighted analytic sample was reduced to 760 White respondents. Because the missing cases comprised only $1.3 \%$ of the sample, no need existed for data imputation in the multivariate analyses. The YouGov sample of White respondents has the following characteristics: $48.9 \%$ male; 20.5\% with Bachelor's degree; $51.5 \%$ married; mean age of 50.9 $(\mathrm{SD}=17.8) ; 33.2 \%$ Republicans versus $28.8 \%$ Democrats; $18.2 \%$ from the Northeast, $38.1 \%$ from the South, 22.7\% from the Midwest, and 20.9\% are from the West (see Table 1).

\section{----Insert Table 1 About Here----}

\section{Independent Variables}

Racial Measures. The study's focus is on the potential impact of Racial Sympathy on support for capital punishment and related policy views. As discussed previously, Chudy (2017, 2018 , in press) created an innovative measure of this predictor, developing four vignettes that describe situations involving the negative treatment of African Americans. The respondents were then asked "How much sympathy do you have for" those described as experiencing discrimination in each vignette ("Laurette," "the applicants," "the Whittier community leaders," and "Michael"). Possible responses were: 1 = a great deal of sympathy, 2 = a lot of sympathy, 3 = some sympathy, 4 = a little sympathy, and $5=\mathrm{I}$ do not feel any sympathy (for the person/groups specified). Items were recoded so that higher values reflected greater sympathy. The Racial Sympathy measure is a mean scale with a Cronbach's alpha of .796 (factor loadings = .677 to .876). As noted, the vignettes are presented in Appendix A.

Also as discussed above, the study includes the standard four-item measure of Racial Resentment (Kinder \& Sanders, 1996; Chudy, in press). The respondents' response options ranged from $1=$ strongly agree to $5=$ strongly disagree. The four items of this scale are: (1) "It is really a matter of some people not trying hard enough; if Blacks would only try harder, they 
could be just as well off as Whites"; (2) "Irish, Italians, Jewish, and many other minorities overcame prejudice and worked their way up. Blacks should do the same without any special favors"; (3) "Over the past few years, Blacks have gotten less than they deserve"; and (4) "Generations of slavery and discrimination have created conditions that make it difficult for Blacks to work their way out of the lower class." Items 3 and 4 were reverse coded such that higher scores indicated greater resentment. Racial Resentment is a mean scale with a Cronbach's alpha of .884 (factor loadings $=.847$ to .878 ).

Political Orientation. Political orientation was measured by whether the respondents identified themselves as Republican and Conservative. Consistent with previous research (King \& Wheelock, 2007; Shelley et al., 2017), these measures were dichotomized to avoid loss of cases for those who answered "Not sure" (an option included in the YouGov core item for these variables) - 32 cases for party affiliation and 57 cases for ideology. Thus, they were coded as follows: $1=$ Republican, $0=$ others; $1=$ conservative or very conservative; $0=$ others). As a check, the data were also analyzed with ordinal measures of these variables, but no substantive differences were found in the relationships of racial resentment, racial sympathy, and the four outcomes explored.

Cultural Beliefs. We adapted questions from Filindra and Kaplan $(2016,2017)$ to measure egalitarianism. Egalitarianism is a mean scale $(\alpha=.823$, factor loadings $=.656$ to .824$)$ measured with responses $(1=$ strongly agree, $5=$ strongly disagree $)$ to six items about whether the government should ensure equality (e.g., "Our society should do whatever is necessary to make sure that everyone has an equal opportunity to succeed"; "One of the biggest problems in this country is that we don't give everyone an equal chance"). Items were coded so that higher scores indicate more support for equality and thus egalitarian values. 
Religiosity. This is a standardized mean scale $(\alpha=.826$, factor loadings $=.860$ to .921$)$ computed from three questions measuring the importance of religion in respondents' lives, their frequency of praying, and their frequency of attending church.

Care/Harm Moral Foundation. This is a mean scale $(\alpha=.542$, factor loadings $=.631$ to .669) based on responses ( $1=$ strongly agree, $5=$ strongly disagree) to four items measuring moral intuitions about harm and care (e.g., "It can never be right to kill a human being"; "The government must first and foremost protect all people from harm"). These items were adapted from the work of Graham, Haidt, and Nosek (2009).

Salience of Crime/Threat. To measure respondents' perceptions of crime salience and threat, we used two measures: fear of crime and dangerous world beliefs. Fear of Crime is a mean scale $(\alpha=.904$, factor loadings $=.790$ to .900$)$ based on responses to five questions that asked how afraid respondents were that someone in their household would fall victim to five crimes (theft, burglary, robbery, sexual assault, murder) in the next five years. Higher values indicate greater fear of crime. From the work of Stroebe, Leander, \& Kruglanski (2017), we also included a measure of dangerous world beliefs. Thus, Dangerous World is a mean scale ( $\alpha=$ .794 , factor loadings $=.741$ to .836$)$ based on responses $(1=$ strongly agree, $5=$ strongly disagree) to four items that asked about the security and stability of the social order (e.g., "There are many dangerous people in our society who will attack someone out of pure meanness, for no reason at all"). Responses were coded so that higher scores indicate a greater belief that the world is unpredictable and dangerous.

Controls. Measures were included for the standard socio-demographic control variables of Age (in years), gender ( $1=$ Male), Education ( $1=$ no high school, $6=$ graduate degree), marital status $(1=$ Married $)$, employment status $(1=$ Full-Time Employment $)$, and region of 
residence $(1=$ Southerner $)$. Southerner is coded as residing in a state in the South as defined by the Census Bureau Regions and Divisions (see https://www2.census.gov/geo/docs/mapsdata/maps/reg_div.txt). Missing cases $(n=88 ; 11.4 \%)$ precluded the use of family income as a control. This is a common problem in YouGov studies because the income question includes the response option of "prefer not to say" (see, e.g., Haner, Cullen, Jonson, Burton, \& Kulig, 2019). Table 1 provides the descriptive statistics for all of the variables.

\section{Dependent Variables}

To assess the respondents' policy views, we included three measures used extensively in previous research (Burton, Cullen, Burton, Graham, Butler, \& Thielo, 2020; Enns, 2016): support for the death penalty, support for harsher courts, and belief that the main goal or "emphasis" of prisons should be rehabilitative rather than punitive. The wording for these measures was taken from questions employed for decades by the General Social Survey (death penalty and harsher courts questions) and by the Harris Poll (main goal of prisons question) (see Cullen et al., 2000; Enns, 2016). As noted, a measure of perceived racial discrimination in the death penalty also was included. The central measures in the analysis assess public views toward capital punishment.

Two capital punishment measures were employed. First, the respondents' support $(1=$ favor, 0 = oppose/no opinion) for the Death Penalty was measured by asking: "Do you favor or

oppose the death penalty for a person convicted of murder?"3 Second, to assess Chudy's (2017, in press) claim that racial sympathy is more likely to predict responses to policies that affect African Americans, we included a question on Death Penalty Racial Discrimination. The stem of this item read as follows: "One debate is whether capital punishment is given out fairly or discriminates against minorities, especially African Americans who murder a White person. 
Which of these statements best reflects your views on the death penalty?" The response options included: 1 = The courts in the U.S. are "colorblind"-everyone is equally likely to get the death penalty; $2=$ African Americans are a little more likely to get the death penalty than Whites; $3=$ African Americans are much more likely to get the death penalty than Whites; and $4=$ White people in the U.S. are, if anything, more likely to get the death penalty than African Americans. We code this as $1=$ discrimination against African Americans (answers 2 and 3 ) and $0=$ no discrimination against African Americans (answers 1 and 4).

Beyond capital punishment, Harsher Courts was measured by asking: "In general, do you think the courts in this area deal too harshly or not harshly enough with criminals?" Responses were coded such that $1=$ not harsh enough and $0=$ don't know/about right/too harsh. Finally, support for a Rehabilitation Goal of Prisons $(1=$ rehabilitation, 0 = punishing the individual/protecting society/not sure) was measured by asking: "What do you think should be the main emphasis in most prisons - punishing the individual convicted of a crime, trying to rehabilitate the individual so that he or she might return to society as a productive citizen, or protecting society from future crimes he or she might commit?"

\section{Results}

\section{Racial Sympathy as a Distinct Construct}

Chudy's contribution regarding racial sympathy hinges on the empirical issue of its distinctiveness from racial resentment. She argues that sympathy and resentment are not two ends of the same continuum but separate racial beliefs. Recall that she examined this issue by including her measures as a module of the 2013 Cooperative Congressional Election Study (CCES) administered by YouGov/Polimetrix. In her work, Chudy (2017, 2018, in press) provides empirical support for her thesis. First, as seen in Table 2, her data show that the four 
vignettes load on the same factor in factor analysis, explain 59\% of the variation, and are significantly correlated $(r=-.45)$ with racial resentment. Second, in Table 3, we report her data revealing that, when analyzed together, racial sympathy and resentment load on separate factors. Her case for treating these constructs as distinct is thus strong.

\section{-----Insert Tables 2 and 3 About Here-----}

A key contribution of the current study is that we are able to replicate Chudy's analysis with our main YouGov study and two Amazon MTurk studies-all conducted in 2019 (see Appendix B for MTurk sample characteristics). The goal is to establish whether racial sympathy can be used in studies of racial beliefs in the social sciences, including criminology. As seen in Tables 2 and 3, with few exceptions, our analyses are very similar to Chudy's, lending clear and additional support to considering racial sympathy and resentment as separate constructs. The MTurk Study 2's factor loadings differ by degree in some instances but, even here, the results are comparable. ${ }^{4}$ The MTurk Study 1 and the YouGov Study report findings remarkably similar to Chudy's. A comparison of Chudy's Study with the YouGov Study is particularly relevant because each survey used a national-level sample and similar methodology.

Four results merit attention. First, the Cronbach's alpha for racial sympathy is very similar (e.g., Chudy $\alpha=.74$, YouGov $\alpha=.796$ ). Second, the correlation between racial sympathy and resentment is comparable (Chudy $r=-.45$, YouGov $r=-.500$ ). Third, the four factor loadings for racial sympathy in Table 2 between Chudy and the YouGov study differ by no more than .056 (Vignette $2-$ Chudy $=.82$, YouGov $=.876$ ). Fourth, when analyzed together, racial sympathy and resentment load on distinct factors for both studies (see Table 3).

\section{Effects of Racial Sympathy and Resentment}


Capital Punishment. Having replicated Chudy's findings, the second stage is to assess whether racial sympathy is a predictor of criminal justice policy views. The main focus is on capital punishment, with other outcomes supplementing this analysis. The key comparison is with racial resentment because of its consistent effect of increasing punitiveness. Does racial sympathy reduce support for the death penalty with racial resentment in the same model?

As seen in Table 1, the zero-order correlations between racial sympathy (as well as racial resentment) and support for the death penalty are significant and in the expected direction. In the multivariate analysis that omits racial resentment, racial sympathy is not statistically significant (see Model 1, Table 4). By contrast, consistent with previous research, racial resentment is a robust predictor of support for the death penalty (Odds Ratio $[\mathrm{OR}]=2.180$ ), controlling for a range of other predictors (see Table 4, Model 2). Racial sympathy remains non-significant.

The key test of Chudy's perspective is the relationship between racial sympathy and the race-specific measure of Death Penalty Racial Discrimination. In this case, racial sympathy is related to this outcome both as a zero-order correlation (Table 1) and without racial resentment in the multivariate analysis (Table 1, Model 3; OR = 1.698). Importantly, in Model 4, racial sympathy retains statistical significance with resentment added into the analysis. Note as well that racial sympathy has an impact even though the care/harm moral foundation and egalitarianism are also significant. Also worth mentioning is that dangerous world view had significant effects across all models in Table 4 and, as we will see, in Table 5 ahead.

\section{-----Insert Tables 4 and 5 About Here-----}

General Effects. Now we consider whether racial sympathy has general effects beyond death penalty opinions. As seen in Table 1 where the correlations are presented and in Table 5 (Models 1 and 3) where the multivariate analyses are presented, racial sympathy is significantly 
associated with both harsher courts and rehabilitation as a goal of imprisonment in the expected direction. The key analyses are reported on Models 2 and 4 in Table 5 where racial resentment is introduced into the analyses. As expected by Chudy's work, racial resentment renders spurious the effect of racial sympathy on support for harsher courts. However, this is not the case with regard to offender treatment. As seen in Model 4, racial sympathy retains a significant effect on support for rehabilitation as the goal of imprisonment. Again, this impact occurs even with care/harm and egalitarianism in the model.

\section{Discussion}

This project is a case study in concept transfer, focusing on the transmission of the emerging construct of racial sympathy from political science to criminology. In the past, criminology has benefitted from the importation of knowledge from other social sciences, including the concept of racial resentment. The broader point here is that the process of transferring a concept can be done not only informally but also in a more formal or explicit way. That is the approach taken in this project, which seeks to enrich the understanding of how racial beliefs shape policy preferences. Five considerations structure our discussion to follow.

\section{Concept Transfer}

First, as noted the particular value of the current project is that it introduces into the criminological literature the concept of racial sympathy, recently developed by political scientist Jennifer Chudy (2017, 2018, in press). Until this time in political science and beyond, the racial attitude of resentment had played a central role in explaining how racial beliefs affect public policy preferences. Chudy's (in press) unique contribution was to suggest that another racial belief—White's distress over Blacks' suffering — was distinct from racial resentment and 
consequential in its effects. The current project presents the first test of Chudy's claim that these two racial beliefs are in fact separate constructs. Importantly, we replicate independently—and across three different national-level data sets - Chudy's (2017) finding that racial sympathy is distinct from racial resentment. The pattern of results, including factor loadings, are remarkably similar, especially with our YouGov national sample. These results provide important evidence confirming Chudy's contention that racial sympathy is a racial belief that merits inclusion in studies of public opinion regarding policies. In and of itself, this analysis represents a significant contribution to the social science literature.

\section{Effects of Racial Resentment}

Second, a key criminological fact is that racial beliefs shape policy preferences.

Consistent with a wealth of past research (e.g., Brown \& Socia, 2017; Unnever et al., 2008), our analysis showed that racial resentment is a robust predictor of punitive attitudes. Even with a number of controls in the multivariate analyses, such animus not only increased support for capital punishment and harsher courts but also eliminated the effects of racial sympathy. Racial resentment also leads people to deny that the death penalty is racially biased and to oppose rehabilitating incarcerated offenders. Resentment seems to induce a certain callousness about sanctioning, where inflicting pain on offenders is embraced and considering offenders' unjust treatment and potential needs is ignored. These findings also lend credence to criminologists' concerns about the racial, if not racist, basis of the justice system (see, e.g., Alexander, 2010; Tonry, 2011).

We should note, however, the debate within political science over the measure of racial resentment (for a discussion, see Hutchings \& Valentino, 2004). One criticism of the racial resentment scale is that it conflates anti-black sentiment with individualism. Therefore, the 
relationship between racial resentment and racial policies may be driven not by prejudice but by principles linking individual merit and effort to the attainment of the American Dream—a "belief in hard work, self-reliance," and the existence of "an open opportunity structure" (Jardina \& Stephens-Dougan, 2018, p. 6; see also Feldman \& Huddy, 2005). Kinder and Sanders's (1996) response is that their racial resentment scale was intended to capture not only racial prejudice, but also "prejudice expressed in the language of American individualism" (p. 106; see also Simmons \& Bobo, 2018). In an effort to assess the effect of "racially tinged" individualism beyond the effect of individualism alone, researchers have included measures of individualism or similar constructs as control variables in models predicting racial policies as well as non-raciallyspecific criminal justice policies. These studies show that, controlling for individualism, libertarianism, egalitarianism, or attribution of criminal behavior to individual failings, racial resentment continues to be a significant predictor of public opinion on a range of issues (Filindra \& Kaplan, 2016, 2017; Johnson, 2008; O’Brien et al., 2013). Notably, in our analyses, racial resentment exerted robust effects with a control for egalitarianism in the model.

One further issue, ignored in public policy studies, warrants notice. Although an assessment of racial sympathy evokes the recognized need to include a general measure of concern for others, research on racial resentment does not include a general measure of resentment. Dictionaries define resentment as "indignation or ill will stemming from a feeling of having been wronged or offenders" ("Resentment," 2020). Resentment may be situational but also dispositional. Scales have been developed to measure gratitude and resentment (see Duran, 2017; Watkins, Woodward, Stone, \& Kolts, 2003). Future studies should include a control for resentment so as to confirm the robust effects of racial resentment.

\section{Effects of Racial Sympathy}


Third, the analysis demonstrates that racial sympathy has effects on policy preferences independent of racial resentment and in the way hypothesized by Chudy. Racial sympathy was non-significant in the multivariate model for support for the death penalty and was rendered spurious when racial resentment was entered into analysis for support for harsher courts. These policies were not explicitly racial as asked. Note that the care/harm moral foundation did reduce support for the death penalty in line with research showing that empathy and similar factors manifest this association (see, e.g., Applegate et al., 2000; Godcharles et al., 2019; Unnever \& Cullen, 2007a; Unnever, Cullen, \& Applegate, 2005, Unnever et al., 2006; Unnever, Cullen, \& Fisher, 2005). By contrast, even with significant effects found for racial resentment, care/harm, and egalitarianism, the analysis revealed that racial sympathy heightened perceptions that the death penalty was racially discriminatory. Again, Chudy (in press) was clear that as a "racial attitude," racial sympathy's effect should have effects on public support of policies that affect African Americans.

The analysis also revealed that racial sympathy was significantly related to support for rehabilitation as the main goal of imprisonment. Although this finding pertained only to a single question (albeit a standard item in national polls and academic studies), it suggests that racial sympathy might be an important source of support for a broad range of rehabilitative-human services policies (e.g., offender reentry, use of community alternative to incarceration, expanding treatment programs, reducing the collateral consequences of a felony conviction). Future research should explore the generality of the effects of racial sympathy. Further, inquiries should consider how racial sympathy influences views toward sentencing and correctional policies that affect African Americans directly. Again, Chudy's thesis is that racial sympathy is particularly 
salient when respondents are asked their opinions about policies that are race-specific and/or impact African Americans differentially.

\section{Fitting into Criminology}

Fourth, the purpose of this project has been to establish empirically that racial sympathy is distinct from racial resentment and to alert criminologists to its emerging importance and potential utility. As noted, however, there is an extant body of research within criminology that examines the relationship of racial beliefs to punitiveness, including death penalty support. How will racial sympathy fit into that line of inquiry?

Although waning in recent years, concerted efforts were made by officials on the political right to "play the race card" - that is, to link crime, especially violent crime, to African Americans. In the so-called "southern strategy," Republican candidates sought to capture White voters by stereotyping Blacks as welfare cheats and super-predators (Maxwell \& Shields, 2019; Tonry, 2011). The nourishing of racial resentment was one result. Another was the view of offenders as the "dangerous other" (Garland, 2001, p. 180), and the strong association of race and crime - so much so as to create the stereotype of the "criminalblackman" (Russell-Brown, 2009; see also Unnever \& Gabbidon, 2011). The consequences of this thinking are disquieting. The "psychology of American race relations," notes Tonry (2011, p. 79, emphasis added), is “characterized by stereotypes of black criminals, unconscious preferences for whiteness over blackness, and lack of empathy among whites for black offenders and their families."

Notably, research shows that punitiveness will be higher when Whites see Blacks as more violent than themselves, attribute Blacks' waywardness to bad character rather than bad circumstances, and have little empathy for the plight of Black offenders (Metcalfe et al., 2015; Unnever \& Cullen, 2012). Racial sympathy should mitigate these proximate cognitive causes of 
punitiveness versus African Americans. The hallmark of racial sympathy is Whites' distress over Blacks' suffering. Those high on this belief should reject negative racial stereotypes, embrace causal attributions that see African Americans' offending as arising from inequitable social circumstances, and have "empathetic identification" with Blacks who they view as entrapped unfairly in a criminal life-course (see Unnever \& Cullen, 2009). They should thus favor more lenient punishments (Chudy, in press). Harboring a belief in the redeemablity of offenders, they should also endorse progressive, human service-oriented interventions that seek to save Blacks' from a life in crime rooted in disadvantage and suffering (see Burton et al., 2020).

\section{Future Concept Transfer}

Finally, criminology should continue to profit from developments within political science — and elsewhere — regarding the role of racial beliefs in shaping policy preferences. As noted in the introduction, the outpouring of Whites' racial sympathy—-from a presidential candidate to GenZ demonstrators-makes Chudy's work on the concept's development and measurement potentially significant. We would argue that criminological studies of race-related policies, whether in punishment or policing, should incorporate Chudy's racial sympathy scale as a standard measure in the analysis. The study of racial beliefs should not be limited to racial resentment and similar measure of racial animus—only one side of the coin.

Another line of inquiry also merits attention. Until this time, most research has focused on attitudes toward people of color. Now, however, there is a growing literature focusing on how views about "whiteness" affects public opinion. Beyond White supremacy, which involves a toxic mixture of racism and White hierarchical privilege, scholars are now probing the importance of White identity and consciousness in shaping policy preferences, including support 
for Donald Trump (see, e.g., Jardina, 2019; Kaufmann, 2019; Maxwell \& Shields, 2019; see also Hochschild, 2016). This orientation might be called White nationalism or "ethno-traditional nationalism" (Kaufmann, 2019). These views about a desire to value White culture, traditions, and demographic majority are empirically related to, but distinct from, racial animus. The point is that similar to political science, the next generation of research on racial beliefs in criminology will profit from examining not only White attitudes toward minorities but also toward themselves.

\section{Notes}

1. Examples of White racial sympathy in the media are ubiquitous; two will suffice to make this point. First, former president George W. Bush commented: "Laura and I are anguished by the brutal suffocation of George Floyd and disturbed by the injustice and fear that suffocate our country.... It remains a shocking failure than many African Americans, especially young African American men, are harassed and threatened in their own country" (Neumann, 2020). Second, Joe Burrow, Heisman Trophy winner and the first overall selection in the 2020 NFL draft remarked: "The black community needs our help. They have been unheard for far too long. Open your ears, listen, and speak. This isn't politics. This is human rights" (Dellenger, 2020).

2. The two items in Kinder and Sanders's (1996) racial resentment study that are excluded from the four-item version of the scale are: (1) "Most blacks who receive money from welfare programs could get along without if they tried"; and (2) "Government officials usually pay less attention to a request or complaint from a black person than from a white person" (p. 106).

3. This wording is taken from the General Social Survey. The Gallup Poll uses a slightly different wording: "Are you in favor of the death penalty for a person convicted of murder?"

4. These MTurk findings (Study 1 and 2) align with Thompson and Pickett's (2019) analyses that finds online samples, such as MTurk, generally produce findings in the same direction of nationally representative samples, but is less capable of accurately estimating the size of those effects. 


\section{References}

Alexander, M. (2010). The new Jim Crow: Mass incarceration in the age of colorblindness. New York, NY: The New Press.

Ansolabehere, S. A., \& Rivers, D. (2013). Cooperative survey research. Annual Review of Political Science, 16, 307-329.

Ansolabehere, S., \& Schaffner, B. F. (2014). Does survey model still matter? Findings from a 2010 multi-mode comparison. Political Analysis, 22(3), 285-303.

Applegate, B. K., Cullen, F. T., Fisher, B. S., \& Vander Ven, T. (2000). Forgiveness and fundamentalism: Reconsidering the relationship between correctional attitudes and religion. Criminology, 38(3), 719-754.

Astor, M. (2020, June 2). Joe Biden listens to anguish at a Black church in Delaware. New York Times. Retrieved from https://www.nytimes.com/2020/06/01/us/politics/joe-bidengeorge-floyd.html

Bobo, L. D., \& Johnson, D. (2004). A taste for punishment: Black and White Americans' views on the death penalty and the war on drugs. Du Bois Review, 1(1), 151-181.

Bobo, L., Kluegel, J. R., \& Smith, R. A. (1997). Laissez-faire racism: The crystallization of a kinder, gentler, antiblack ideology. In S. A. Tuch \& J. K. Martin (Eds.), Racial attitudes in the 1990s: Continuity and change (pp. 15-42). Westport, NY: Praeger.

Bonilla-Silva, E. (2019). Feeling race: Theorizing the racial economy of emotions. American Sociological Review, 84(1), 1-25.

Brown, T. N., Bento, A., Gorman, Q., Jr., Koku, L., \& Culver, J. (2019). "Who cares?”: Investigating consistency in expressions of racial apathy among Whites. Socius, 5, 1-10.

Brown, E. K., \& Socia, K. M. (2017). Twenty-first century punitiveness: Social sources of punitive American views reconsidered. Journal of Quantitative Criminology, 33(4), 935959.

Burton, A. L., Cullen, F. T., Burton, V. S., Jr., Graham, A., Butler, L. C., \& Thielo, A. J., (2020). Belief in redeemability and punitive public opinion: "Once a criminal always a criminal" revisited. Criminal Justice and Behavior, 47(6), 712-732.

Butler, L., Unnever, J. D., Cullen, F. T., \& Thielo, A. J. (2018). Public opinion about the death penalty. In R. M. Bohm \& G. Lee (Eds.), Routledge handbook on capital punishment (pp. 55-70). New York, NY: Routledge. 
Chappell, B. (2020, June 2). 'He did not pray': Fallout grows from Trump's photo-op at St. John's Church. NPR. Retrieved from https://www.npr.org/2020/06/02/867705160/he-didnot-pray-fallout-grows-from-trump-s-photo-op-at-st-john-s-church

Chudy, J. (2017). Racial sympathy in American politics (Unpublished doctoral dissertation). University of Michigan, Ann Arbor.

Chudy, J. (2018, February 16). Racial sympathy and its limits. Paper presented at the Research in American Politics Workshop, Boston University.

Chudy, J. (in press). Racial sympathy and its political consequences. Journal of Politics. doi.org/10.1086/708953

Cullen, F. T., Fisher, B. S., \& Applegate, B. K. (2000). Public opinion about punishment and corrections. In M. Tonry (Ed.), Crime and justice: A review of research (Vol. 14, pp. 179). Chicago, IL: University of Chicago Press.

Death Penalty. (2019). Gallup - in depth: topics A to Z. Retrieved from https://news.gallup.com/poll/1606/death-penalty.aspx

Dellenger, R. (2020, June 2). Ed Orgeron grieving with his nation, players over George Floyd's death: "It's terrible." Sports Illustrated. Retrieved from https://www.si.com/college/2020/06/02/ed-orgeron-statement-george-floyd-death

Dovidio, J. F., \& Gartner, S. L. (2004). Aversive racism. In M. P. Zanna (Ed.), Advances in experimental social psychology (Vol. 36, pp. 1-49). Bingley, England: Emerald Press.

Duran, N. O. (2017). The Revised Short Gratitude, Resentment, and Appreciation Test (SGRAT): Adaptation for Turkish college students. Journal of Happiness and Well-Being, 5(1), 23-37.

Easley, C. (2020, June 1). Floyd protests are backed by most Americans as more say racism isn't taken seriously enough. Morning Consult. Retrieved from https://morningconsult.com/2020/06/01/floyd-protests-are-backed-by-most-americans-asmore-say-racism-isnt-taken-seriously-enough/

Enns, P. K. (2016). Incarceration nation: How the United States became the most punitive democracy in the world. New York, NY: Cambridge University Press.

Feldman, S., \& Huddy, L. (2005). Racial resentment and white opposition to race-conscious programs: principles or prejudice? American Journal of Political Science, 49(1), 168183.

Filindra, A., \& Kaplan, N. J. (2016). Racial resentment and Whites' gun policy preferences in contemporary America. Political Behavior, 38(2), 255-275. 
Filindra, A., \& Kaplan, N. (2017). Testing theories of gun policy preferences among Blacks, Latinos, and Whites in America. Social Science Quarterly, 98(2), 413-428.

Forman, T. A., \& Lewis, A. E. (2006). Racial apathy and Hurricane Katrina: The social anatomy of prejudice in the post-Civil Rights era. Du Bois Review, 3(1), 175-202.

Garland, D. (2001). The culture of control: Crime and social order in contemporary society. Chicago, IL: University of Chicago Press.

Glueck, K. (2020, June 2). Joe Biden laces into Trump for fanning 'flames of hate.' New York Times. Retrieved from https://www.nytimes.com/2020/06/02/us/politics/joe-bidenphiladelphia-protests.html

Godcharles, B. D., Rad, J. D. J., Heide, K. M., Cochran, J. K., \& Solomon, E. P. (2019). Can empathy close the racial divide and gender gap in death penalty support? Behavioral Sciences \& the Law, 37(1), 16-37.

Graham, A., Haner, M., Sloan, M. M., Cullen, F. T., Kulig, T. C., \& Jonson, C. L. (2020). Race and worrying about police brutality: The hidden injuries of minority status in America. Victims \& Offenders. Advance online publication. doi: 10.1108/PIJPSM-07-2019-011

Graham, J., Haidt, J., \& Nosek, B. A. (2009). Liberals and conservatives rely on different sets of moral foundations. Journal of Personality and Society Psychology, 96(5), 1029-1046.

Haidt, J. (2012). The righteous mind: Why good people are divided by politics and religion. Vintage.

Haner, M., Cullen, F. T., Jonson, C. L., Burton, A. L., \& Kulig, T. C. (2019). Price of liberty or never again: Americans' views on preventing mass murder. Justice Evaluation Journal, 2(1), 50-72.

Henderson, M., \& Hillygus D. S. (2011). The dynamics of health care opinion, 2008-2010: Partisanship, self-interest, and racial resentment. Journal of Health Politics, Policy and Law, 36(6), 945-960.

Henry, P. J., \& Sears, D. O. (2002). The symbolic racism 2000 scale. Political Psychology, 23(2), 253-283.

Hutchings, V. L., \& Valentino, N. A. (2004). The centrality of race in American politics. Annual Review of Political Science, 7, 383-408.

Iyer, A., Leach, C. W., \& Crosby, F. J. (2003). White guilt and racial compensation: the benefits and limits of self-focus. Personality and Social Psychology Bulletin, 29(1), 117-129.

Jardina, A. (2019). White identity politics. Cambridge, England: Cambridge University Press. 
Jardina, A., \& Stephens-Dougan, L. (2018). Disentangling race and individualism. Paper presented at the annual meeting of the American Political Sciences Association, Boston, MA.

Johnson, D. (2008). Racial prejudice, perceived injustice, and the Black-White gap in punitive attitudes. Journal of Criminal Justice 36(2), 198-206.

Kaufmann, E. (2019). Whiteshift: Populism, immigration, and the future of White majorities. New York, NY: Abrams Press.

Kawakami, K. Dion, K. L., \& Dovidio, J. F. (1998). Racial prejudice and stereotype activation. Personality and Social Psychology Bulletin, 24(4), 407-416.

Kennedy, C., Mercer, A., Keeter, S., Hatley, N., McGeeney, K., \& Gimenez, A. (2016). Evaluating online nonprobability surveys. Washington, DC: Pew Research Center.

Kinder, D. R., \& Sanders, L. M. (1996). Divided by color: Racial politics and democratic ideals. Chicago, IL: University of Chicago Press.

King, R. D., \& Wheelock, D. (2007). Group threat and social control: race, perceptions of minorities, and the desire to punish. Social Forces, 85(3), 1255-1280.

Maxwell, A., \& Shields, T. (2019). The long southern strategy: How chasing White voters in the South changed American politics. New York, NY: Oxford University Press.

McConahay, J. B. (1982). Self-interest versus racial attitudes as correlates of anti-busing attitudes in Louisville: Is it the buses or the Blacks? Journal of Politics, 44(3), 692-720.

Mears, D. P., Pickett, J. T., Mancini, C. (2015). Support for balanced juvenile justice: Assessing views about youth, rehabilitation, and punishment. Journal of Quantitative Criminology, 31(3), 459-479.

Mercer, A. W., Kreuter, F., Keeter, S., \& Stuart, E. A. (2017). Theory and practice in nonprobability surveys: Parallels between causal inference and survey inference. Public Opinion Quarterly, 81(S1), 250-271.

Metcalfe, C., Pickett, J. T., \& Mancini, C. (2015). Using path analysis to explain racialized support for punitive delinquency policies. Journal of Quantitative Criminology, 31(4), $699-725$.

Miller, Z., Lemire, J., \& Balsamo, M. (2020, June 3). Trump offers 'domination' of D.C. protests as model for states. Military Times. Retrieved from https://www.militarytimes.com/news/your-military/2020/06/02/trump-offers-dominationof-dc-protests-as-model-for-states/ 
Neumann, S. (2020, June 2). George W. Bush says he's 'anguished' over George Floyd's death: 'It is time for us to listen.' People. Retrieved from https://people.com/politics/georgelaura-bush-anguished-over-george-floyd-death/

O’Brien, K., Forrest, W., Lynott, D., \& Daly, M. (2013). Racism, gun ownership and gun control: Biased attitudes in U.S. Whites may influence policy decisions. PLoS One, 8 , e77552.

Oliphant. J. B. (2018, June 11). Public support for the death penalty ticks up. Pew Research Center. Retrieved from https://www.pewresearch.org/fact-tank/2018/06/11/us-supportfor-death-penalty-ticks-up-2018/

Pickett, J. T., \& Baker, T. (2014). The pragmatic American: empirical reality or methodological artifact? Criminology, 52(2), 195-222.

Resentment. (2020). Resentment. The Free Dictionary. Retrieved from https://www.thefreedictionary.com/resentment

Russell-Brown, K. (2009). The color of crime: Racial hoaxes, white fear, black protectionism, police harassment, and other microaggressions (2nd ed.). New York, NY: New York University Press.

Sanders, D., Clarke, H. D., Stewart, M. C., \& Whiteley, P. (2007). Does mode matter for modeling political choice? Evidence from the 2005 British Election Study. Political Analysis, 15(3), 57-285.

Segura, G. M., \& Valenzuela, A. A. (2010). Hope, tropes, and dopes: Hispanic and White racial animus in the 2008 election. Presidential Studies Quarterly, 40(3), 497-514.

Shelley, W. W., Pickett, J. T., Mancini, C., McDougle, R. D.., Rissler, G., \& Cleary, H. (2017.) Race, bullying, and public perceptions of university safety. Journal of Interpersonal Violence. Advance online publication. doi.org/10.1177/0886260517736272

Silver, J. R. (2017). Moral foundations, intuitions of justice, and the intricacies of punitive sentiment. Law \& Society Review, 51(2), 413-450.

Silver, J. R., \& Silver, E. (2017). Why are conservatives more punitive than liberals? A moral foundations approach. Law and Human Behavior, 41(3), 258-272.

Simmons, A. D., \& Bobo, L.D. (2015). Can non-full-probability internet surveys yield useful data? A comparison with full-probability face-to-face surveys in the domain of race and social inequality attitudes. Sociological Methodology, 45(1), 357-387.

Simmons, A. D., \& Bobo, L. D. (2018). Understanding "no special favors": A quantitative and qualitative mapping of the meaning of responses to the racial resentment scale. Du Bois Review, 15(2), 323-352. 
Sloas, L. B., \& Atkin-Plunk, C. A. (2019). Perceptions of balanced justice and rehabilitation for drug offenders. Criminal Justice Policy Review, 30(7), 990-1009.

Stroebe, W., Leander, N. P., \& Kruglanski, A.W. (2017). Is it a dangerous world out there? The motivational bases of American gun ownership. Personality and Social Psychology Bulletin, 4(8), 1071-1085.

Thielo, A. J., Graham, A., \& Cullen, F. T. (in press). Opt-in internet surveys. In J. C. Barnes \& D. R. Forde (Eds.), The encyclopedia of research methods and statistical techniques in criminology and criminal justice. New York, NY: Wiley.

Thompson, A. J., \& Pickett, J. T. (2019). Are Relational Inferences from Crowdsourced and Optin Samples Generalizable? Comparing Criminal Justice Attitudes in the GSS and Five Online Samples. Journal of Quantitative Criminology, 1-26. Advance online publication. doi.org/10.1007/s10940-019-09436-7

Tonry, M. (2011). Punishing race: A continuing American dilemma. New York, NY: Oxford University Press.

Tuch, S. A., \& Hughes, M. (2011). Whites' racial policy attitudes in the twenty-first century: The continuing significance of racial resentment. ANNALS of the American Academy of Political and Social Science, 634(1), 134-152.

Unnever, J. D., Cochran, J. K., Cullen, F. T., \& Applegate, B. K. (2010). The pragmatic American: Attributions of crime and the hydraulic relation hypothesis. Justice Quarterly, 27(3), 431-457.

Unnever, J. D., \& Cullen, F. T. (2007a). Reassessing the racial divide in support for capital punishment: the continuing significance of race. Journal of Research in Crime and Delinquency, 44(1), 124-158.

Unnever, J. D., \& Cullen, F. T. (2007b). The racial divide in support for the death penalty: does white racism matter? Social Forces, 85(3), 1281-1301.

Unnever, J. D., \& Cullen, F. T. (2009). Empathetic identification and punitiveness: A middlerange theory of individual differences. Theoretical Criminology, 13(3), 283-312.

Unnever, J. D., \& Cullen, F. T. (2010a). The social sources of Americans' punitiveness: a test of three competing models. Criminology, 48(1), 99-129.

Unnever, J. D., \& Cullen, F. T. (2010b). Racial-ethnic intolerance and support for capital punishment: a cross-national comparison. Criminology, 48(3), 831-864.

Unnever, J. D., \& Cullen, F. T. (2012). White perceptions of whether African Americans are prone to violence and support for the death penalty. Journal of Research in Crime and Delinquency, 49(4), 519-544. 
Unnever, J. D., \& Cullen, F. T., \& Applegate, B. K. (2005). Turning the other cheek: reassessing the impact of religion on punitive ideology. Justice Quarterly, 22 (3), 304-339.

Unnever, J. D., Cullen, F. T., \& Bartkowski, J. P. (2006). Images of God and public support for capital punishment: Does a close relationship with a loving God matter? Criminology, 44(4), 835-866.

Unnever, J. D., Cullen, F. T., \& Fisher, B. S. (2005). Empathy and support for capital punishment. Journal of Crime and Justice, 28(1), 1-34.

Unnever, J. D., Cullen, F. T., \& Jonson, C. L. (2008). Race, racism, and support for capital punishment. In M. Tonry (Ed.), Crime and Justice: A review of research (Vol. 37, pp. 45-96). Chicago, IL: University of Chicago Press.

Unnever, J. D., \& Gabbidon, S. L. (2011). A theory of African American offending: Race, racism, and crime. New York, NY: Routledge

Vaughan, T. J., Holleran, L. B., \& Silver, J. R. (2019). Applying moral foundations theory to the explanation of capital jurors' sentencing decisions. Justice Quarterly, 36(7), 1176-1205.

Vavreck, L., \& Rivers, D. (2008). The 2006 Cooperative Congressional Election Study. Journal of Elections, Public Opinion and Parties, 18(4), 355-366.

Watkins, P.C., Woodward, K., Stone, T. \& Kolts, R.D. (2003). Gratitude and happiness: The development of a measure of gratitude and its relationship with subjective well-being. Social Behavior and Personality, 31(5), 431-452.

Wise, A. (2020, June 1). Trump calls governors weak, urging them to 'dominate' to quell violence. NPR. Retrieved from https://www.wbur.org/npr/867063007/trump-callsgovernors-weak-and-urges-them-to-dominate-violent-protesters

Zimring. F. E. (2017). When police kill. Cambridge, MA: Harvard University Press. 
Appendix A. Racial sympathy vignettes

\section{Items:}

How much sympathy do you have for the person described in each of the scenarios below?

1. Michael is a young black man who lives in a Midwestern city. One day Michael is crossing the street and jaywalks in front of cars. Some local police officers see Michael jaywalk and stop and question him. Michael argues that he was just jaywalking and is otherwise a lawabiding citizen. The police officers feel that Michael is being uncooperative and so they give him a pat down to see if he is carrying any concealed weapons. Michael is very upset by this treatment.

2. Milford is a mid-sized city in the Northeast. The main bus depot for the city is located in the Whittier section of Milford, a primarily black neighborhood. Whittier community leaders argue that the concentration of buses produces serious health risks for residents; they point to the high asthma rates in Whittier as evidence of the bus depot's harmful effects. The Milford Department of Transportation officials, who are mostly white, state that Whittier is the best location for the depot because it is centrally located and many Whittier residents take the bus. Furthermore, it would be expensive to relocate the bus depot to a new location. Whittier community leaders are very upset by the Department's inaction.

3. Tim is a white man who owns a hair salon. His business is growing rapidly and so he decides to place an advertisement to hire new stylists. In the advertisement, he writes that interested applicants should come for an interview first thing next Monday. When he arrives at the salon on Monday, he sees a line of seven or eight people waiting outside the door, all of whom appear to be black. He approaches the line and tells the applicants that he's sorry, but the positions have been filled. The applicants are upset; they feel they have been turned away because of their race.

4. Mrs. Lewis, a white woman with young children, posts advertisements for a nanny on community bulletin boards. She receives many inquiries and decides to interview all applicants over the phone. Mrs. Lewis is most impressed with a woman named Laurette, who has relevant experience, is an excellent cook, and comes enthusiastically recommended. Mrs. Lewis invites Laurette over for what she expects will be the final step of the hiring process. When Laurette arrives, Mrs. Lewis is surprised to see that Laurette is black. After Laurette's visit, which goes very well, Mrs. Lewis thanks her for her time but says that she will not be offered the job. When Laurette asks why, Mrs. Lewis says that she doesn't think that her children would feel comfortable around her. Laurette is upset about Mrs. Lewis' actions.

Responses: 1 = a great deal of sympathy, $2=$ a lot of sympathy, $3=$ some sympathy, $4=$ a little sympathy, $5=$ I do not feel any sympathy [Laurette/the applicants/Whittier community leaders/Michael] 
Appendix B. Descriptive statistics for Amazon MTurk samples

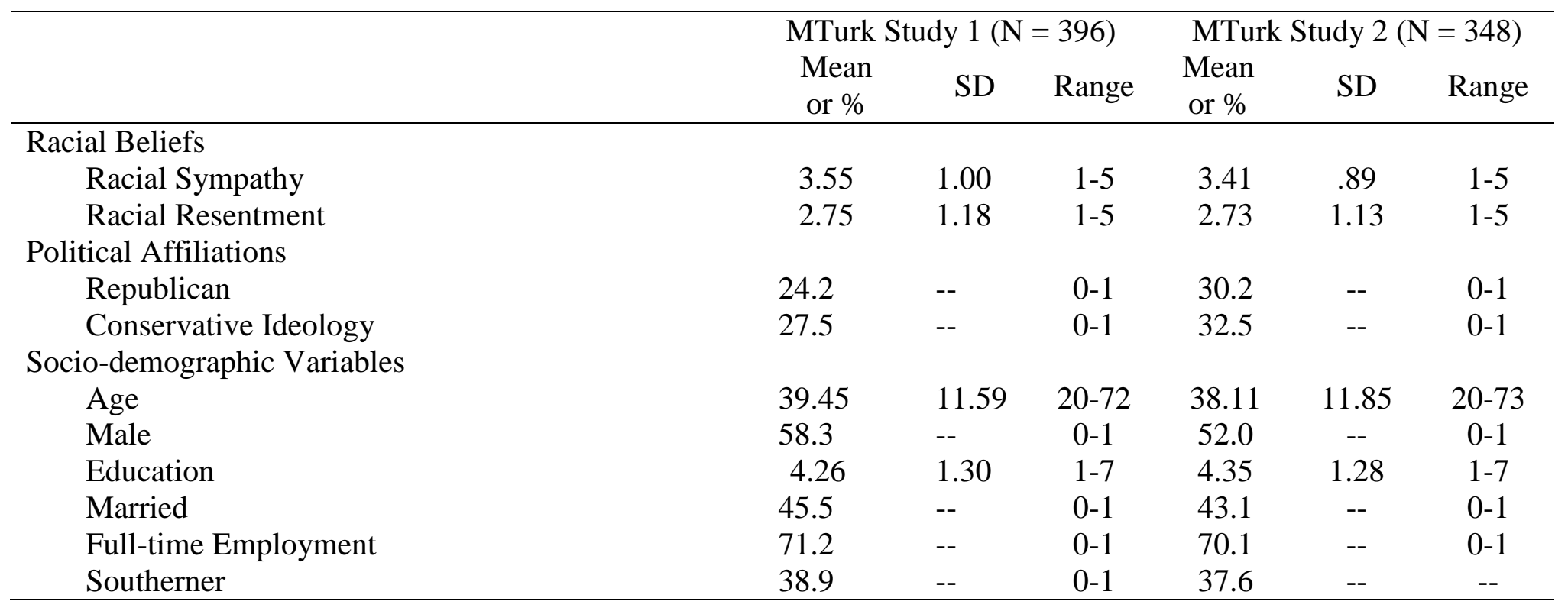


Table 1. YouGov sample descriptive statistics $(\mathrm{N}=760)$

\begin{tabular}{|c|c|c|c|c|c|c|c|}
\hline & \multirow[b]{2}{*}{$\begin{array}{l}\text { Mean } \\
\text { or \% }\end{array}$} & \multirow[b]{2}{*}{ SD } & \multirow[b]{2}{*}{ Range } & \multicolumn{4}{|c|}{ Correlations with Outcomes } \\
\hline & & & & $\begin{array}{l}\text { Death } \\
\text { Penalty }\end{array}$ & $\begin{array}{c}\text { Harsher } \\
\text { Courts }\end{array}$ & $\begin{array}{l}\text { Rehabilitation } \\
\text { Goal of } \\
\text { Imprisonment }\end{array}$ & $\begin{array}{c}\text { Death Penalty } \\
\text { Racial } \\
\text { Discrimination }\end{array}$ \\
\hline \multicolumn{8}{|l|}{ Outcome Variables } \\
\hline Death Penalty & 56.2 & -- & $0-1$ & -- & $.416^{*}$ & $-.409 *$ & $-.395^{*}$ \\
\hline Harsher Courts & 42.2 & -- & $0-1$ & $.419 *$ & -- & $-.296 *$ & $-.269 *$ \\
\hline Rehabilitation Goal of Imprisonment & 41.7 & -- & $0-1$ & $-.409 *$ & $-.296 *$ & -- & $.345^{*}$ \\
\hline Death Penalty Racial Discrimination & 47.8 & -- & $0-1$ & $-.395 *$ & $-.269 *$ & $.345^{*}$ & -- \\
\hline \multicolumn{8}{|l|}{ Racial Beliefs } \\
\hline Racial Sympathy & 3.58 & 1.01 & $1-5$ & $-.277 *$ & $-.243^{*}$ & $.323 *$ & $.376^{*}$ \\
\hline Racial Resentment & 3.15 & 1.44 & $1-5$ & $.527 *$ & $.409 *$ & $-.411^{*}$ & $-.618^{*}$ \\
\hline \multicolumn{8}{|l|}{ Political Affiliations } \\
\hline Republican & 33.2 & -- & $0-1$ & $.313 *$ & $.219 *$ & $-.224^{*}$ & $-.369 *$ \\
\hline Conservative Ideology & 37.9 & -- & $0-1$ & $.423 *$ & $.322 *$ & $-.297 *$ & $-.389 *$ \\
\hline \multicolumn{8}{|l|}{ Cultural Beliefs } \\
\hline Egalitarianism & 3.20 & .68 & $1-5$ & $-.430 *$ & $-.343^{*}$ & $.409 *$ & $.550 *$ \\
\hline Religiosity (Z-score) & .01 & .89 & $-1.35-1.41$ & $.111 *$ & $.164 *$ & $-.202 *$ & $-.270^{*}$ \\
\hline Care/Harm Moral Foundation & 3.65 & .71 & $1-5$ & $-.228 *$ & $-.085^{*}$ & $.127 *$ & $.184^{*}$ \\
\hline \multicolumn{8}{|l|}{ Salience of Crime/Threat } \\
\hline Fear of Crime & 2.92 & .99 & $1-5$ & $.111 *$ & $.134 *$ & $-.116^{*}$ & $-.111^{*}$ \\
\hline Dangerous World & 3.48 & .87 & $1-5$ & $.311 *$ & $.340 *$ & $-.261 *$ & $-.345^{*}$ \\
\hline \multicolumn{8}{|l|}{ Control Variables } \\
\hline Age & 50.86 & 17.82 & $19-93$ & $.209 *$ & $.204 *$ & $-.145^{*}$ & $-.122 *$ \\
\hline Male & 48.9 & -- & $0-1$ & -.091 & -.013 & .004 & .038 \\
\hline Education & 3.47 & 1.53 & $0-6$ & $-.138 *$ & $-.081 *$ & $.092 *$ & $.215^{*}$ \\
\hline Married & 51.5 & -- & $0-1$ & $.095^{*}$ & $.095^{*}$ & $-.098^{*}$ & $-.074 *$ \\
\hline Full-time Employment & 40.6 & -- & $0-1$ & -.013 & -.030 & .055 & .044 \\
\hline Southerner & 38.1 & -- & $0-1$ & $.114 *$ & .039 & $-.075^{*}$ & $-.106^{*}$ \\
\hline
\end{tabular}

Notes: The data are weighted. ${ }^{*} \mathrm{p}<.05$ (two-tailed) 
Table 2. Comparison of racial sympathy

\begin{tabular}{|c|c|c|c|c|}
\hline Statistical Properties & $\begin{array}{l}\text { Chudy } \\
\text { Study }\end{array}$ & $\begin{array}{l}\text { MTurk } \\
\text { Study } 1\end{array}$ & $\begin{array}{l}\text { MTurk } \\
\text { Study } 2\end{array}$ & $\begin{array}{l}\text { YouGov } \\
\text { Study }\end{array}$ \\
\hline $\mathrm{N}$ & 751 & 396 & 348 & 760 \\
\hline $\begin{array}{l}\text { Racial Sympathy Scale } \\
\text { Cronbach's Alpha }\end{array}$ & .74 & .778 & .659 & .796 \\
\hline Factor Loadings for Vignettes & & & & \\
\hline Vignette 1: Laurette--hiring & .81 & .859 & .827 & .846 \\
\hline Vignette 2: Hair salon applicants & .82 & .835 & .859 & .876 \\
\hline Vignette 3: Community leaders & .67 & .737 & .552 & .677 \\
\hline Vignette 4: Michael--police & .72 & .667 & .529 & .765 \\
\hline Explained Variance & $58 \%$ & $60.57 \%$ & $50.17 \%$ & $63.15 \%$ \\
\hline $\begin{array}{l}\text { Correlation of Racial Sympathy Scale } \\
\text { with Racial Resentment Scale }\end{array}$ & -.45 & -.511 & -.360 & -.500 \\
\hline
\end{tabular}


Table 3. Comparison of racial sympathy and racial resentment*

\begin{tabular}{|c|c|c|c|c|c|c|c|c|}
\hline \multirow{2}{*}{$\begin{array}{l}\text { Statistical Properties } \\
\text { Factor Loadings }\end{array}$} & \multicolumn{2}{|c|}{$\begin{array}{l}\text { Chudy } \\
\text { Study }\end{array}$} & \multicolumn{2}{|c|}{$\begin{array}{l}\text { MTurk } \\
\text { Study } 1\end{array}$} & \multicolumn{2}{|c|}{$\begin{array}{l}\text { MTurk } \\
\text { Study } 2\end{array}$} & \multicolumn{2}{|c|}{$\begin{array}{c}\text { YouGov } \\
\text { Study }\end{array}$} \\
\hline & Factor 1 & Factor 2 & Factor 1 & Factor 2 & Factor 1 & Factor 2 & Factor 1 & Factor 2 \\
\hline Vignette 1: Laurette-hiring & .10 & .88 & .109 & .938 & .041 & .908 & .072 & .900 \\
\hline Vignette 2: Hair salon applicants & .05 & .86 & .084 & .901 & .024 & .922 & .063 & .922 \\
\hline Vignette 3: Community leaders & -.06 & .63 & -.187 & .621 & -.348 & .334 & -.015 & .661 \\
\hline Vignette 4: Michael—police & -.23 & .58 & -.275 & .482 & -.482 & .248 & -.285 & .591 \\
\hline Racial Resentment_-Irish & .93 & .11 & .875 & .001 & .822 & .078 & .834 & -.020 \\
\hline Racial Resentment-Generations & .88 & .01 & .815 & -.066 & .828 & .047 & .904 & .050 \\
\hline Racial Resentment-Try harder & .79 & -.07 & .912 & .127 & .812 & .047 & .827 & -.047 \\
\hline Racial Resentment-Deserve & .84 & -.02 & .794 & -.084 & .812 & -.029 & .883 & .032 \\
\hline Explained Variance & $43 \%$ & $35 \%$ & $50.696 \%$ & $17.165 \%$ & $41.335 \%$ & $20.343 \%$ & $51.605 \%$ & $17.802 \%$ \\
\hline $\mathrm{N}$ & \multicolumn{2}{|c|}{751} & \multicolumn{2}{|c|}{396} & \multicolumn{2}{|c|}{348} & \multicolumn{2}{|c|}{760} \\
\hline
\end{tabular}

*EFAs using Promax rotation 
Table 4. YouGov data logistic regression models $(\mathrm{N}=760)$

\begin{tabular}{|c|c|c|c|c|c|c|c|c|c|c|c|c|}
\hline & \multicolumn{6}{|c|}{ Death Penalty } & \multicolumn{6}{|c|}{ Death Penalty Racial Discrimination } \\
\hline & \multicolumn{3}{|c|}{ Model 1} & \multicolumn{3}{|c|}{ Model 2} & \multicolumn{3}{|c|}{ Model 3} & \multicolumn{3}{|c|}{ Model 4} \\
\hline & $\mathrm{b}$ & $(\mathrm{SE})$ & OR & $\mathrm{b}$ & $(\mathrm{SE})$ & OR & $\mathrm{b}$ & $(\mathrm{SE})$ & OR & $\mathrm{b}$ & $(\mathrm{SE})$ & OR \\
\hline \multicolumn{13}{|l|}{ Racial Beliefs } \\
\hline Racial Sympathy & -.033 & .102 & .968 & .185 & .110 & 1.203 & .530 & .108 & $1.698 * * *$ & .267 & .117 & $1.307 *$ \\
\hline Racial Resentment & -- & -- & -- & .779 & .119 & $2.180 * * *$ & -- & -- & -- & -1.308 & .144 & $.270 * * *$ \\
\hline \multicolumn{13}{|l|}{ Political Affiliations } \\
\hline Republican & .417 & .249 & 1.518 & .221 & .254 & 1.248 & -.922 & .237 & $.398 * * *$ & -.723 & .251 & $.485^{* *}$ \\
\hline Conservative Ideology & 1.489 & .257 & $4.425 * * *$ & 1.147 & .266 & $3.148 * * *$ & -.629 & .241 & $.533 * *$ & .000 & .265 & 1.000 \\
\hline \multicolumn{13}{|l|}{ Cultural Beliefs } \\
\hline Egalitarianism & -.018 & .207 & .982 & .058 & .213 & 1.060 & .534 & .211 & $1.706^{*}$ & .510 & .224 & $1.665^{*}$ \\
\hline Religiosity & -.074 & .119 & .929 & -.201 & .127 & .818 & -.276 & .118 & $.758 *$ & -.144 & .131 & .866 \\
\hline Care/Harm Moral Foundation & -.913 & .163 & $.402 * * *$ & -.736 & .170 & $.479 * * *$ & .614 & .158 & $1.847 * * *$ & .365 & .175 & $1.441^{*}$ \\
\hline \multicolumn{13}{|l|}{ Salience of Crime/Threat } \\
\hline Fear of Crime & .225 & .103 & $1.253^{*}$ & .255 & .107 & $1.291 *$ & .094 & .106 & 1.099 & .078 & .116 & 1.081 \\
\hline Dangerous World & .587 & .127 & $1.798 * * *$ & .397 & .136 & $1.488 * *$ & -.616 & .133 & $.540 * * *$ & -.308 & .152 & $.735^{*}$ \\
\hline \multicolumn{13}{|l|}{ Control Variables } \\
\hline Age & .021 & .006 & $1.022 * * *$ & .015 & .006 & $1.015^{*}$ & -.002 & .006 & .998 & .010 & .006 & 1.010 \\
\hline Male & .103 & .190 & 1.109 & .107 & .197 & 1.113 & .233 & .195 & 1.262 & .273 & .212 & 1.313 \\
\hline Education & -.183 & .064 & $.833 * *$ & -.122 & .066 & .885 & .314 & .065 & $1.369 * * *$ & .235 & .071 & $1.265^{* *}$ \\
\hline Married & .072 & .188 & 1.074 & .086 & .195 & 1.090 & -.085 & .193 & .919 & -.117 & .211 & .889 \\
\hline Full-time Employment & .591 & .209 & $1.806^{* *}$ & .621 & .219 & $1.861 * *$ & -.317 & .211 & .728 & -.316 & .236 & .729 \\
\hline Southerner & .296 & .189 & 1.344 & .280 & .195 & 1.323 & -.233 & .191 & .792 & -.226 & .207 & .798 \\
\hline Constant & -.394 & 1.125 & .675 & -3.650 & 1.264 & .026 & -4.187 & 1.158 & .015 & .337 & 1.309 & 1.401 \\
\hline Cox \& Snell R-square & & .293 & & & .336 & & & .322 & & & .412 & \\
\hline
\end{tabular}

Notes: The data are weighted. $* \mathrm{p}<.05, * * \mathrm{p}<.01, * * * \mathrm{p}<.001$ (two-tailed) 
Table 5. YouGov data logistic regression models $(\mathrm{N}=760)$

\begin{tabular}{|c|c|c|c|c|c|c|c|c|c|c|c|c|}
\hline & \multicolumn{6}{|c|}{ Harsher Courts } & \multicolumn{6}{|c|}{ Rehabilitation as Goal of Imprisonment } \\
\hline & \multicolumn{3}{|c|}{ Model 1} & \multicolumn{3}{|c|}{ Model 2} & \multicolumn{3}{|c|}{ Model 3} & \multicolumn{3}{|c|}{ Model 4} \\
\hline & $\mathrm{b}$ & $(\mathrm{SE})$ & OR & $\mathrm{b}$ & $(\mathrm{SE})$ & OR & $\mathrm{b}$ & $(\mathrm{SE})$ & OR & $\mathrm{b}$ & $(\mathrm{SE})$ & OR \\
\hline \multicolumn{13}{|l|}{ Racial Beliefs } \\
\hline Racial Sympathy & -.231 & .095 & $.808 *$ & -.091 & .099 & .913 & .508 & .102 & $1.661 * * *$ & .388 & .105 & $1.474 * * *$ \\
\hline Racial Resentment & -- & -- & -- & .507 & .108 & $1.661 * * *$ & -- & -- & -- & -.455 & .106 & $.634 * * *$ \\
\hline \multicolumn{13}{|l|}{ Political Affiliations } \\
\hline Republican & .056 & .218 & 1.057 & -.036 & .220 & .965 & -.118 & .229 & .889 & -.006 & .231 & .994 \\
\hline Conservative Ideology & .806 & .226 & $2.238 * * *$ & .552 & .233 & $1.738 *$ & -.609 & .234 & $.544 * *$ & -.370 & .242 & .691 \\
\hline \multicolumn{13}{|l|}{ Cultural Beliefs } \\
\hline Egalitarianism & -.020 & .189 & .980 & .015 & .191 & 1.015 & .271 & .194 & 1.311 & .214 & .195 & 1.239 \\
\hline Religiosity & -.042 & .110 & .959 & -.113 & .113 & .894 & -.123 & .108 & .885 & -.057 & .111 & .945 \\
\hline Care/Harm Moral Foundation & -.257 & .140 & .773 & -.125 & .145 & .883 & .269 & .141 & 1.309 & .130 & .147 & 1.139 \\
\hline \multicolumn{13}{|c|}{ Salience of Crime/Threat } \\
\hline Fear of Crime & .128 & .097 & 1.137 & .135 & .099 & 1.144 & -.065 & .096 & .937 & -.071 & .097 & .931 \\
\hline Dangerous World & .725 & .123 & $2.065 * * *$ & .590 & .128 & $1.804 * * *$ & -.342 & .115 & $.711 * *$ & -.215 & .121 & .806 \\
\hline \multicolumn{13}{|l|}{ Control Variables } \\
\hline Age & .019 & .005 & $1.019 * * *$ & .015 & .005 & $1.015^{* *}$ & -.007 & .005 & .9933 & -.002 & .005 & .998 \\
\hline Male & -.162 & .181 & .850 & -.164 & .184 & .849 & .211 & .179 & 1.235 & .213 & .181 & 1.237 \\
\hline Education & -.056 & .059 & .946 & -.005 & .061 & .995 & .057 & .059 & 1.058 & .009 & .060 & 1.009 \\
\hline Married & .180 & .177 & 1.197 & .183 & .180 & 1.201 & -.283 & .175 & .754 & -.296 & .178 & .774 \\
\hline Full-time Employment & .360 & .195 & 1.434 & .333 & .198 & 1.395 & -.056 & .190 & .945 & -.040 & .194 & .961 \\
\hline Southerner & -.087 & .176 & 917 & -.098 & .178 & .906 & -.120 & .175 & .887 & -.098 & .177 & .906 \\
\hline Constant & -2.770 & 1.044 & .063 & -4.779 & 1.147 & .008 & -2.069 & 1.058 & .126 & -.143 & 1.154 & .867 \\
\hline Cox \& Snell R-square & \multicolumn{3}{|c|}{.200} & \multicolumn{3}{|c|}{.224} & \multicolumn{3}{|c|}{.183} & \multicolumn{3}{|c|}{.203} \\
\hline
\end{tabular}

Notes: The data are weighted. $* \mathrm{p}<.05, * * \mathrm{p}<.01, * * * \mathrm{p}<.001$ (two-tailed) 